UDC 621.396.677.75

A. Voloshyn, Yu. Prokopenko, Ph.D.

National Technical University of Ukraine "Kyiv Polytechnic Institute",

Peremogy, ave. 37, Kiev, 03056, Ukraine.

\title{
Alteration and radiation characteristics of frequency tunable ring DRA
}

A frequency tunable ring dielectric resonator antenna is presented in the paper. Advantages of the proposed antenna design are the wide range of adjustments and increasing of the radiation efficiency. The basic antenna characteristics, and also analysis of dependencies of the antenna's central operating frequency, voltage standing wave ratio and radiation pattern versus the relative position of the ring dielectric resonator parts are presented. The influence of the inner to outer ring radius ratio on the efficiency of frequency tuning, radiation efficiency are investigated. References 6 , figures 5 .

Keywords: dielectric resonator antenna, ring dielectric resonator, frequency tuning, antenna characteristics.

\section{Introduction}

The most part of modern mobile devices, such as cellular phones, notebooks or tablets use several wireless services and technologies, such as GSM, Bluetooth, Wi-Fi, LTE, simultaneously. So, high efficient, small-size multi-band or tunable antennas are highly preferable for these devices. Since the dielectric resonator antenna (DRA) has negligible metallic loss, it is highly efficient and has compact size when operates at millimeter and submillimeter wave frequencies. Considering this advantage, in additional to low cost and easy of fabrication, DRAs are very promising kind of antennas for further researches.

Few DRA frequency tuning methods are known [2-3]. In paper [2], DRA frequency tuning ratio is controlled by loading elements, such as chip capacitors or chip varactors. In each loading case, a frequency-tunable DRA with good match and stable radiation patterns is obtained. However, the inclusion of the varactor or varicap in the dielectric resonator (DR) leads to a decrease of total antenna efficiency. In paper [3], mechanical method is used for tuning DRA with $T M_{01 \delta}$ mode excitation. Unfortunately, tuning range of this method has significant limitations $<10 \%$.

\section{Design of the DRA and Its Alteration Character- istics}

For increasing the tuning efficiency, another micromechanical method is proposed. The method is based on possibility to change effective permittivity and consequently the resonant frequency of dielectric resonator (DR), which is central DRA operating frequency, over disturbance of the electromagnetic field through perturbation. Strong disturbance of the electromagnetic field in the DR is archived by intentionally introducing an air gap between DR's parts and controlled by small displacement between them. DR crossed by an air slot is also named composite dielectric resonator (CDR). The main difference from the earlier proposed methods that dielectric discontinuity as air gap should be placed perpendicularly to electrical field of the resonator, which increases efficiency of resonant frequency alteration and expands the tuning range up to $30 \%$ [4].

The aperture-coupling excitation method with a waveguide feedline (Fig. 1) is used for excitation the ring $C D R$ at main $T E_{01}$ mode, because $D R$ is easily accommodated in the waveguide without additional coupling elements and easily agreed with him [5]. Ring CDR, where $R_{0}, R_{i}$ is outer and inner ring radius, respectively, $h$ is height of the ring, $d$ is air gap size, is positioned in the center of non-emitting aperture at the front end of the waveguide. Dimensions of the rectangular aperture $b_{x}, b_{y}$ are larger than CDR dimensions, but chosen smaller than waveguide' wall dimensions a and $b$. 


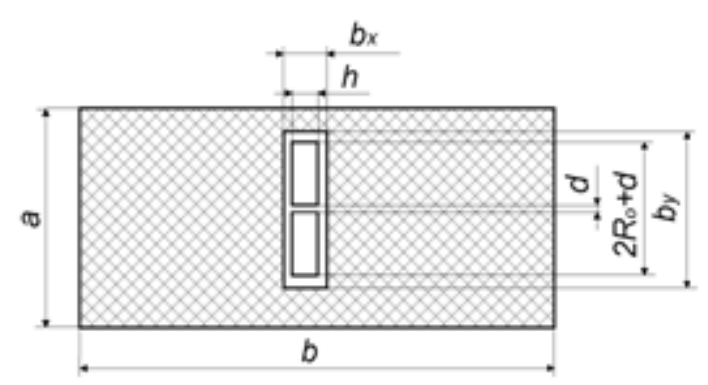

a)

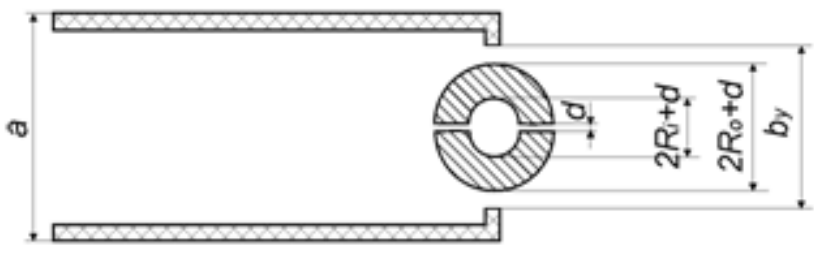

b)

Fig. 1. Design of the ring DRA excited by waveguide. a) Front view; b) Side view

The finite-difference time-domain method has been used for investigation of DRA's alteration and radiation characteristics.

It is convenient to present calculated values of CDR resonant frequency versus air gap in normalized coordinates (Fig. 2), which have no dependency on absolute geometrical parameters and frequency band. The normalized wavenumbers are $\sqrt{\varepsilon} k R_{0}$, where $\varepsilon=80$ is dielectric permittivity, $k=2 \pi f_{0} / c$ is the resonant wavenumber, $f_{0}$ is resonant frequency of the main mode, $C$ is the light velocity.

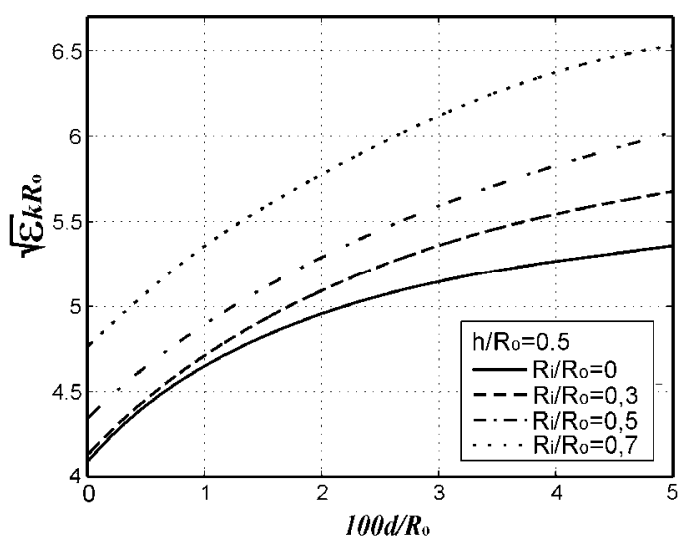

Fig. 2. Normalized resonant wave number versus normalized distance between composite ring dielectric resonator parts for different ratios of the inner to the outer radius $R_{i} / R_{0}$

As it is seen in Fig. 2 the efficiency of resonant frequency alteration is high - the range of the resonant frequency tuning reaches several tens percent while distance between parts of ring CDR is only a few percent from dimension of the resonators. Required absolute displacement of air gap is only tens micrometers in centimeter wavelength bands.
Frequency tuning range reaches $\sim 30 \%$. As well normalized wavenumber rises up with increasing of inner to outer radius ratio.

\section{Tunable Ring DRA Radiation Characteristics}

Radiation efficiency $e$ of the antenna is the ratio of the radiated power to the total power which can also be expressed in terms of $Q$-factors as:

$$
e=\frac{P_{\text {rad }}}{P_{\text {rad }}+P_{\text {dis }}}=1-\frac{Q_{1}}{Q_{0}},
$$

where $P_{\text {rad }}$ is radiated power, $P_{\text {dis }}$ is power dissipated as heat, $Q_{l}$ is loaded $Q$-factor, $Q_{0}$ is unloaded $Q$-factor, which includes dissipation losses of the CDR.

Dielectric discontinuity as air gap placed perpendicular to DR electrical field leads to redistribution of the electromagnetic field energy. Amount of energy stored in the air gap, where practically no losses, increases which leads to increase of the unloaded Q-factor. This effect is also confirmed by the results presented in paper [6]. So, according to (1) radiation efficiency increases while unloaded Qfactor increasing, as it is shown in Fig. 3.

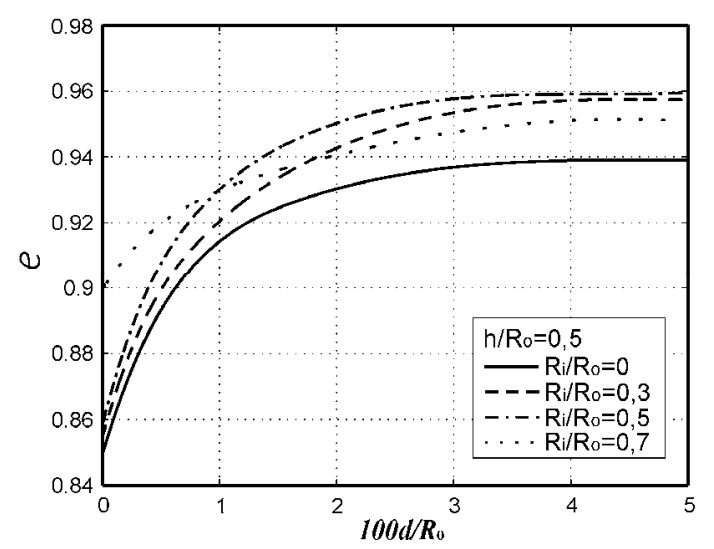

Fig. 3. Variations of the radiation efficiency of ring DRA versus air gap size for different $R_{i} / R_{0}$ ratios 
It is seen in Fig. 3 that radiation efficiency can be increased up to $10 \%$. The higher radiation efficiency is obtained with the highest $R_{i} / R_{0}$ ratio.

From the other hand air gap insertion entails a change of CDR impedance, which leads to mismatch between the transmission line and the antenna, changing voltage standing wave ratio (VSWR), which is shown in Fig. 4.a. However, it was found that VSWR could be improved while re-

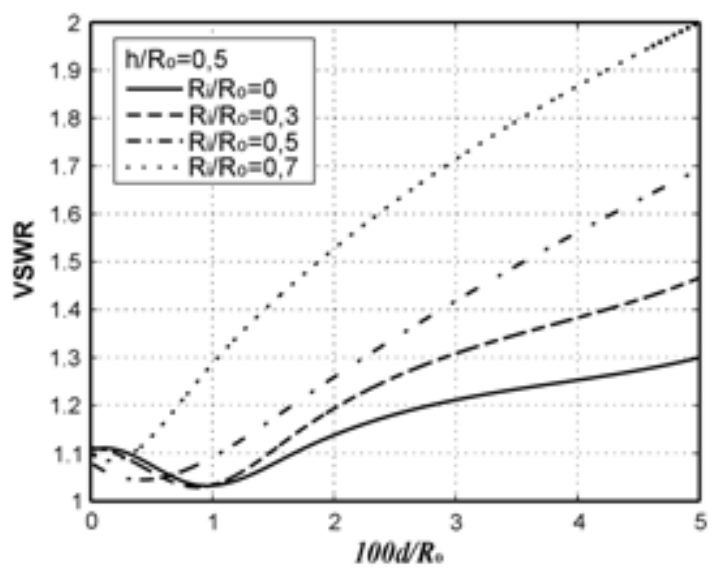

a) ducing waveguide geometrical size, expressed in terms of waveguide's cutoff wavelenght $\lambda_{c}$ with respect to the resonant wavelength $\lambda_{0}$ without tuning (Fig. 4.b). It is seen in figures that there is a distance between the ring CDR parts where VSWR is lower and respectively agreement between DR and waveguide feedline is the best.

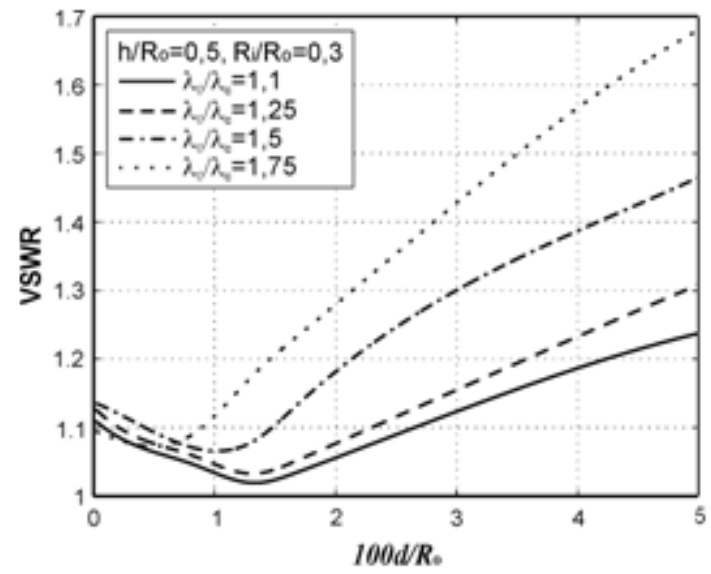

b)

Fig. 4. Variations of the VSWR of ring DRA versus air gap size for different ratios of a) $R_{i} / R_{0}$ radius; b) $\lambda_{c} / \lambda_{0}$ wavelengths

The total antenna efficiency, which takes into account losses at the input terminals, because of the mismatch between the transmission line and the antenna and within the structure of the antenna is not degradate (or increase for lower $R_{i} / R_{0}$ ratio) during frequency tuning. Increase of the VSWR

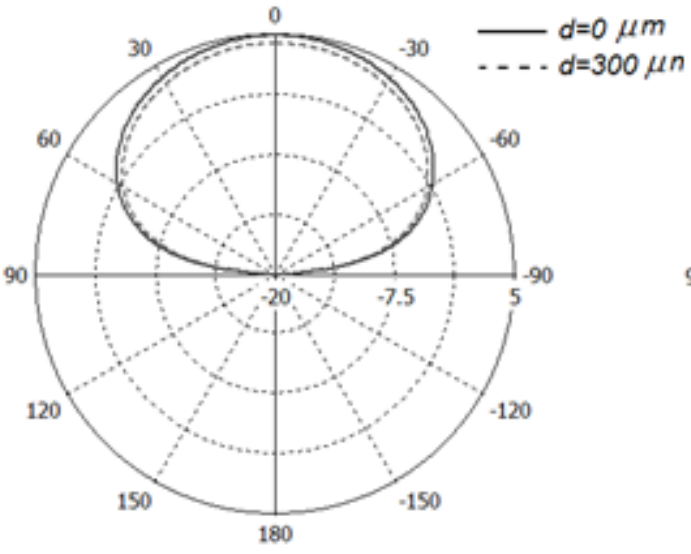

a) is compensated by radiation efficiency increasing.

Radiation pattern is shown in Fig. 5 for DRA with $R_{i} / R_{0}=0,5, h / R_{0}=0,5$, where it can be visible that air gap insertion doesn't significant affect the field pattern at the far field region and doesn't change far field radiation patterns form.

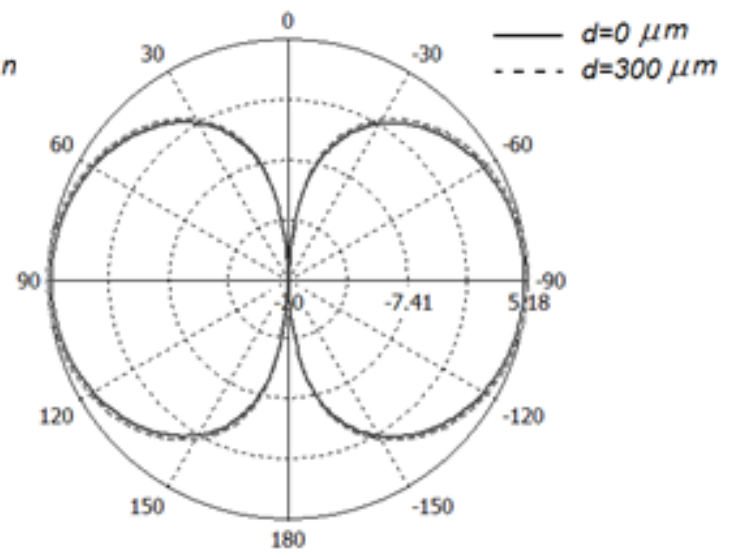

b)

Fig. 5. Radiation patterns for the ring DRA a) $E_{\theta}, \varphi=0$; b) $E_{\varphi}, \theta=\pi / 2$

\section{Conclusion}

Micromechanical frequency tuning method and the design of the frequency tunable ring DRA excited by waveguide were proposed. Main DRA's alteration and radiation characteristics were obtained and analyzed.

Alteration of operating frequencies can be archived by insertion of dielectric discontinuity as 
air gap in cross-section perpendicular to the electric field lines, which leads to shift of its operating frequency up to $30 \%$ without degradation of total antenna efficiency and far field radiation pattern. Due to the high tunable efficiency, small continuous displacement between ring CDR's parts can be easily achieved by modern piezoelectric or MEMS actuators.

While designing a compromise should be found between alteration and radiation characteristics when selecting the $R_{i} / R_{0}$ ratio of ring $\mathrm{DR}$. Waveguide dimensions should also be considered for improving radiation characteristics.

\section{References}

1. Kwai-Man Luk, Kwok-Wa Leung (2003), "Dielectric Resonator Antenna," England, Baldock, Research Studies Press Ltd. P. 388.

2. C. X. Hao, K.W. Leung and X. Q. Sheng (2011), "Frequency-Tunable Differentially Fed Rectangular Dielectric Resonator Antennas". IEEE Transactions Antennas and Propagation Society. Vol. 10, pp. 884-887.
3. G.P. Junker, A.A. Kishk, A.W. Glisson and D.Kajfe (1994), "Effect of air gap on optical dielectric resonator antenna operating in TM01 mode". Electronics letters. Vol. 30, no. 2, pp. $97-98$.

4. Poplavko Yu.M., Prokopenko Yu.V., Molchanov V.I., Dogan A. (2001), "Frequency-tunable microwave dielectric resonator". IEEE Transactions on Microwave Theory and Techniques. Vol. 48, pp. 1020-1027.

5. A. Trubin (2009), "Microwave antennas, based on dielectric resonators circular arrays". National Technical University of Ukraine "KPI" Journal - Radio Engineering. Vol. 38, pp. 78 83.

6. B. Pratsiuk, K. Savin, P. Sergiyenko, Y. Prokopenko (2011), "Improving of dielectric resonator coupling with rectangular waveguide". Proc. Of SPIE Photonics Applications in Astronomy, Communications, Industry and High-Energy Physics Experiments. Vol. 8008.

Поступила в редакцию 20 сентября 2014 г.

УдК 621.396.677.75

А.О. Волошин, Ю.В. Прокопенко, канд.техн.наук

Національний технічний університет України «Київський політехнічний інститут», пр. Перемоги, 37, Київ, 03056, Україна.

\section{Характеристики частотної перебудови та випромінювання перестроюваної кільцевої дієлектричної резонансної антени}

В статmі представлена частотно-перестроювана кільцева діелектрична резонансна антена. Перевагами запропонованої конструкиії антени є широкий діапазон перестройки і підвищення ефрективності випромінювання. Представлені основні характеристики антени, а також аналіз залежностей центральної робочої частоти антени, коефіцієнту стоячої хвилі та діаграм спрямованості в залежності від відносного положення кільцевих частин діелектричного резонатора. Був досліджений вплив відношення внутрішнього до зовнішнього радіусів кільцевого діелектричного резонатора на ефективність перебудови частоти та ефективність випромінювання. Бібл. 6, рис. 5.

Ключові слова: діелектрична резонансна антена, кільцевий діелектричний резонатор, перестроювання частоти, характеристики антени.

(C) Voloshyn A., Prokopenko Yu., 2014 
УДК 621.396.677.75

А.А. Волошин, Ю.В. Прокопенко, канд.техн.наук

Национальный технический университет Украины «Киевский политехнический институт», пр. Победы, 37, Киев, 03056, Украина.

\section{Характеристики частотной перестройки и излучения перестраива- емой кольцевой диэлектрической резонансной антенны}

В статье представлена частотно-перестраиваемая кольцевая диэлектрическая резонансная антенна. Преимуществами предложенной конструкции антенны является широкий диапазон перестройки и увеличение эффрективности излучения. Представлены основные характеристики антенны, а также проведен анализ зависимостей центральной рабочей частоты антенны, коэфициента стоячей волны и диаграмм направленности в зависимости от положения составных частей диэлектрического резонатора. Было исследовано влияние отношение внутреннего к внешнему радиусов кольцевого диэлектрического резонатора на эфрфективность перестройки частоты и эффрективность излучения. Библ. 6, рис. 5.

Ключевые слова: диэлектрическая резонансная антенна, кольцевой диэлектрический резонатор, перестройка частоты, характеристики антенны.

\section{Список использованных источников}

1. Kwai-Man Luk, Kwok-Wa Leung. Dielectric Resonator Antenna. - England, Baldock, Research Studies Press Ltd., 2003. $388 \mathrm{p}$.

2. C. X. Hao, K.W. Leung and X. Q. Sheng Frequency. Tunable Differentially Fed Rectangular Dielectric Resonator Antennas.// IEEE Transactions Antennas and Propagation Society, 2011, vol. 10. pp. 884887.

3. G.P. Junker, A.A. Kishk, A.W. Glisson and D.Kajfe. Effect of air gap on optical dielectric resonator antenna operating in TM01 mode.// Electronics letters, Jan. 1994, Vol. 30, No. 2, pp. 97 - 98.

4. Ю. М. Поплавко, В. И. Молчанов, В. М. Пашков, Ю. В. Прокопенко и др. Перестраиваемые СвЧустройства с электромеханическим управлением.// Техника и приборы СВЧ. - 2009. - Вып.1. - C. $49-59$.

5. Трубин А.А. Микроволновая антенна на основе линейной решетки связанных диэлектрических резонаторов в волноводе.// Вісник Національного технічного університету України «КПІ» Серія Радіотехніка. Радіоапаратобудування. - 2009. - № 38, ст. 78 - 83.

6. B. Pratsiuk, K. Savin, P. Sergiyenko, Y. Prokopenko, "Improving of dielectric resonator coupling with rectangular waveguide".// Proc. Of SPIE Photonics Applications in Astronomy, Communications, Industry and High-Energy Physics Experiments, 2011, Vol. 8008. 